\title{
Evaluation of factors associated with predation on Caiman latirostris nests (Crocodylia: Alligatoridae) in Argentina
}

\author{
Melina Soledad Simoncini ${ }^{1,2}$, María Virginia Parachú Marcó ${ }^{1,2,3}$, Thiago Costa Gonçalves \\ Portelinha $^{1,2,4,5}$, and Carlos Ignacio Piña ${ }^{1,2}$ \\ ${ }^{1}$ Centro de Investigaciones Científicas y Transferencia de Tecnología a la Producción, UAdER-Prov Entre Ríos, CONICET- \\ FCyT, Diamante, Entre Ríos, Argentina. \\ ${ }^{2}$ Proyecto Yacaré, Laboratorio de Zoología Aplicada, Anexo Vertebrados, FHUC-UNL, MASPyMA, Santa Fe, Santa Fe, \\ Argentina. \\ ${ }^{3}$ Instituto de Ciencias Veterinarias del Litoral, UNL-CONICET, Esperanza, Santa Fe, Argentina. \\ ${ }^{4}$ Universidade Federal do Tocantins-UFT, Curso de Engenharia Ambiental, Palmas, TO, Brazil. E-mail: thiagoportelinha@ \\ yahoo.com.br. \\ ${ }^{5}$ Faculdade Católica do Tocantins-FACTO, Escola Politécnica, Palmas, TO, Brazil.
}

\begin{abstract}
Evaluation of factors associated with predation on Caiman latirostris nests (Crocodylia: Alligatoridae) in Argentina. Predation is a major cause of crocodilian egg loss. However, at present, the mechanisms by which predators detect nests is unknown. Previous studies have reported that predators are able to detect prey using both visual and olfactory cues. This study aims to determine the natural predation rate on Broad-snouted Caiman (Caiman latirostris) nests in a "normal" year (i.e., no extreme climatic events) and whether olfactory or visual cues attract predators to caiman nests, and to evaluate the effect of maternal presence on nest predation. In December 2010, we searched for nests in the north of Santa Fe Province, Argentina. Each nest was assigned to one of the following treatments: (1) control nests (nests were observed from a distance to avoid disturbance), (2) visual attraction nests (yellow flagging tapes were tied to vegetation around the nest), (3) olfactory attraction nests (nests were opened, one egg from the clutch was broken, and then the nests were covered again), (4) olfactory attraction from human disturbance (material was manipulated by researchers). The natural predation rate on broad-snouted caiman nests was found to be $21 \%$ during the nesting season. Both olfactory and visual cues were associated with increased predation rates, and human disturbance was strongly associated with increased nest predation at terrestrial sites. Predation rates were less at nests attended by female caiman. Management programs that harvest eggs in wild
\end{abstract}

Received 15 February 2016

Accepted 24 June 2016

Distributed December 2016 
populations (ranching) are predicated on the assumption that removal of some eggs is sustainable, because some will be lost to natural causes (e.g., predation and flooding) and the remaining hatchlings will have improved survival rates. To reduce nest predation of Broad-snouted Caiman between the time when the nest is found and when the eggs are collected, we propose to avoid identification of nest sites with highly visible markings (e.g., flagging tapes tied to vegetation around nests) and to collect eggs immediately after they are found.

Keywords: attraction, Broad-snouted Caiman, eggs, human disturbance, nesting, signs/ tracks, olfactory sensory cues, visual sensory cues.

\begin{abstract}
Resumen
Evaluación de los factores asociados con la predación de nidos de Caiman latirostris (Crocodylia: Alligatoridae) en Argentina. La predación es una de las mayores causas de pérdida de huevos de cocodrilianos. Estudios previos reportan que los predadores detectan a las presas mediante signos visuales u olfativos, por ejemplo los producidos por el hombre. Los objetivos de este estudio son determinar la tasa de predación natural en nidos de yacaré overo (Caiman latirostris), en un año "normal" (e.g., ausencia de eventos climáticos extremos), y a fin de evaluar si las evidencias olfativas o visuales atraen a los predadores a los nidos y si la presencia materna afectaría la predación de los nidos. Para este trabajo, buscamos nidos en el norte de la provincia de Santa Fe (Argentina) durante diciembre de 2010 y los asignamos a los siguientes tratamientos: "control" (nidos observados a la distancia para evitar disturbios), "atracción visual" (cintas amarillas atadas a la vegetación alrededor de los nidos), "atracción olfativa" (los nidos fueron abiertos, uno de los huevos fue roto, y se cubrieron nuevamente los nidos) y "atracción olfativa por disturbios humanos" (el material del nido fue manipulado por los investigadores). Encontramos que, durante una temporada reproductiva en ausencia de eventos climáticos extremos, la predación natural de los nidos de yacaré overo fue del $21 \%$. Observamos que rastros olfativos y visuales incrementan la tasa de predación, y los disturbios humanos estuvieron asociados al incremento de la tasa de predación de nidos en el ambiente terrestre. La tasa de predación fue menor en los nidos que eran atendidos por las hembras. Programas de manejo como la colecta de huevos de las poblaciones naturales (rancheo) son basados en el concepto de la remoción de cierta proporción de huevos es sustentable, ya que se perderían por causas naturales (e.g., predación e inundación). Para reducir la predación de nidos del yacaré overo, entre el momento en que son identificados hasta que son colectados, proponemos evitar la identificación de los nidos con marcas altamente visuales (e.g., cintas móviles alrededor de los nidos), y que la colecta de los huevos sea inmediata.
\end{abstract}

Palabras clave: atracción, disturbios humanos, huevos, nidificación, señales/rastros, señales sensoriales olfativas, señales sensoriales visuales, yacaré overo.

\footnotetext{
Resumo

Avaliação dos fatores associados à predação de ninhos de Caiman latirostris (Crocodylia: Alligatoridae) na Argentina. A predação é uma das maiores causas da perda de ovos em crocodilianos. Estudos prévios demonstraram que os predadores detectam as suas presas por meio de sinais visuais ou olfativos, como os deixados pelo homem. O presente estudo teve como objetivos determinar a taxa de predação natural em ninhos do jacaré-de-papo-amarelo (Caiman latirostris) em um ano "normal" (e.g., ausência de eventos climáticos) e avaliar se estímulos olfativas ou visuais poderiam atrair predadores aos ninhos e se a presença da fêmea afetaria a predação dos mesmos. Para a realização deste trabalho, identificamos e monitoramos ninhos no norte da província de Santa Fé (Argentina) durante o mês de dezembro de 2010, para os quais foram delineados os seguintes tratamentos: "controle" (ninhos somente observados à distância, para evitar distúrbios), "atração visual" (fitas amarelas foram amarradas na vegetação localizada perto dos ninhos), "atração
} 


\begin{abstract}
olfativa" (os ninhos foram abertos, um dos ovos foi quebrado e o ninho foi fechado novamente) e "atração olfativa por ação antrópica" (o material do ninho foi manipulado pelos pesquisadores). Observamos que, em uma temporada reprodutiva, na ausência de eventos climáticos extremos, a predação natural dos ninhos do jacaré-de-papo-amarelo foi de $21 \%$. Também foi observado que os sinais olfativos e visuais aumentam a taxa de predação e que as ações antrópicas estiveram associadas ao incremento da taxa de predação dos ninhos que estavam no ambiente terrestre. A taxa de predação foi menor nos ninhos cuidados pelas fêmeas. Os programas de manejo que realizam coleta de ovos de populações naturais (ranching) são baseados no conceito de que a remoção de um percentual de ovos é sustentável, tendo em vista que alguns desses seriam perdidos por causas naturais (e.g., predação e inundação). Para reduzir a predação dos ninhos do jacaré-de-papo-amarelo, entre o momento de sua identificação e a coleta dos ovos, sugerimos evitar a identificação dos ninhos com marcas visuais (e.g., fitas coloridas perto dos ninhos) e que a coleta de ovos seja imediata.
\end{abstract}

Palavras-chave: ações antrópicas, atração, jacaré-de-papo-amarelo, nidificação, ovos, sinais/rastos, sinais sensoriais olfativos, sinais sensoriais visuais.

\section{Introduction}

One of the most practical approaches to conservation of natural ecosystems is the sustainable use of wild animals and plants of commercial interest from those systems, because economic benefits may stimulate in situ conservation (Larriera 2011). This has been shown to be the case in the Proyecto Yacaré in Argentina (Larriera et al. 2008), which was undertaken to achieve sustainable use of wetlands in Northern Santa Fe Province (Argentina) by raising eggs of free-ranging Caiman latirostris (Daudin 1802) in commercial farms (ranching). This initiative benefits both ranch owners and local inhabitants. The rationale for the harvest of wild eggs for captive rearing is based on the high natural mortality of embryos and hatchlings. The thesis of the project is simple; animals or their eggs that would otherwise die are removed from the wild and commercially raised in captivity, thereby adding economic value to their wetland habitat (Larriera 2011).

During embryonic development, crocodilians are subject to mortality from flooding or predation (Jennings et al. 1987, Woodward et al. 1989, Campos 2003). For the Broad-snouted Caiman (C. latirostris), Larriera and Piña (2000) estimated that during years with extreme climatic events only $30-40 \%$ of eggs hatch because of flooding and predation. Despite many studies of the reproductive biology of $C$. latirostris in Argentina, information regarding nest predation or hatching success in the absence of extreme climatic events is limited. Two studies have estimated the proportion of nests that are lost by predation-41\%, 35 of 85 nests in an exceptionally dry season (Larriera and Piña 2000) and a 16-26\% decline hatchling success caused by red fire ants (Parachú Marcó et al. 2012).

Potential predators of nests of alligatorids in northern Argentina [Caiman latirostris and $C$. yacare (Daudin, 1802)] include South American Coati [Nasua nasua (Linnaeus, 1766)], Crabeating Fox [Cerdocyon thous (Linnaeus, 1766)], Black-and-white Tegu [Salvator merianae (Duméril and Bibron, 1839)], White-lipped Peccary [Tayassu pecari (Link, 1795)], Sixbanded Armadillo [Euphractus sexcinctus (Linnaeus, 1758)], White-eared Opossum (Didelphis albiventris Lund, 1840), and some rats (Larriera and Piña 2000), and Red Fire Ant [Solenopsis invicta (Santschi, 1916)] (Parachú Marcó et al. 2013). Previous studies mentioned that the presence of humans could attract 
predators to crocodilian nests (Deitz and Hines 1980, Magnusson 1982, Campos 1993, Campos and Mourão 2010). Predators locate reptilian eggs based on features related to nest structure or by visual and/or olfactory cues left by the attending female during nest construction and maintenance (Strickland et al. 2010). However, it is unclear whether predators are attracted to crocodilian nests by either olfactory or visual signs, or both. Further, the proportion of nests that are attended by females is unknown and it remains to be demonstrated that their presence influences the likelihood of nest predation as described for other crocodilian species (Lance et al. 2011, Charruau and Hénaut 2012, Savage and Merchant 2012). We undertook this study to determine the natural predation rate on Caiman latirostris nests in a year with normal precipitation, to assess whether either olfactory or visual cues, or both, attract predators to caiman nests, to assess the percentage of nests attended by females, and to determine whether female nest attendance influences predation rates.

\section{Materials and Methods}

We monitored 47 C. latirostris nests at the beginning of the nesting season in December 2010 in the northwestern part of Santa Fe Province (Argentina), where caiman eggs from wild populations are harvested by the Proyecto Yacaré program (based on ranching technique since 1991; Larriera 2011). We considered this year to be a normal because there were no extreme climatic events (e.g., ENOS events "la Niña" or "el Niño"). Rainfall in San Justo Department between 1 November 2010 and 31 January 2011 (the critical period for incubation and development of Caiman latirostris) was $278 \mathrm{~mm}$, which resembles the mean recorded rainfall amount, $264 \pm 147 \mathrm{~mm}$ (mean \pm standard deviation), for this period for the previous five years (between 2005 and 2010; data from the Santa Fe Province's webpage: http://www.santafe.gov.ar/gbrn/regpluv/). Normal rainfall is important to our study design, because predation increases during years with low rainfall (Larriera and Piña 2000).

We searched for nests using a motorized glider and a GPS in sites without tree cover. Nests in forested areas were located visually by researchers searching on foot. We grouped nests in either a terrestrial environment (TE; nests in forest and savannah, $N=20$ ) or an aquatic environment (AE; nests on floating vegetation, $N$ $=27$ ). Based on the characterization of nesting habitats of C. latirostris in Santa Fe Province by Montini et al. (2006), we classified nests in floating vegetation as "Aquatic" because they are located in heavily vegetated water bodies; the nests are built with grass on the surface of the floating vegetation. "Terrestrial" nests are in forest and savannah, and are located on higher plateus or in sites with low slope that occasionally flooded in periods of heavy rain. These nests are found up to $2000 \mathrm{~m}$ from bodies of water, and usually are composed of mud, small stumps, leaves, and grass. Nests were randomly assigned one of the following treatments: (1) Control: nests were observed from a distance and not approached any closer than about $20 \mathrm{~m}$ to avoid disturbance; (2) Visual attraction: yellow flagging tapes were tied to vegetation around nests, so that the wind would move them and potentially attract predators; (3) Olfactory attraction: nests were opened, one egg of the clutch in each nest was broken and left in the egg chamber, and then the nests were covered again; (4) Olfactory attraction from human disturbance: nesting material was manipulated by researchers without contacting the egg chamber, causing no damage to the eggs, with the intention of leaving human olfactory traces.

We measured the development of opaque bands of at least 10 eggs in all nests except the controls to assess fertilization status developmental stage and estimate the time of hatching (Iungman et al. 2008, Simoncini et al. 2013). A week before the estimated hatching date, we returned to inspect nests $(\sim 60-65$ days after the first visit) to ensure that at least $90 \%$ of the incubation period was under natural conditions. 
This procedure could underestimate predation rate because eggs were removed prior to the last few days of incubation. Nests were recorded as depredated if no eggs were found inside or if we found parts of eggshells scattered near nests. Eggs of nests that were not depredated were moved to an artificial incubator of Proyecto Yacaré Program to complete their development. We recorded unequivocal evidence in 43 of 47 nests that females visited (or did not visit) the nest. For both terrestrial and aquatic nests, an attending adult was judged to be present if vegetation around the nest mound was not growing, fresh feces were present, or the top of the nest was compressed, indicating that females had rested there.

We calculated natural predation rates for both terrestrial and aquatic nests (\% nests depredated terrestrial environment $+\%$ nests depredated aquatic environment). We tested the independence of natural predation rates in terrestrial and aquatic nests with a Chi-square test, as well as predation rates of treated aquatic and terrestrial nests. We used Chi-square goodness of fit to test whether nest predation increased on treated nests; control nests were the expected proportion and treated nests the observed values. Last, a Chi-square goodness of fit test was used to analyze whether female nest attendance decreased nest predation only in treated nest; we considered nest predation rates of unattended nests as the expected proportion, and nests with attendance as the observed values. We were only able to test the effect of female attendance on nest predation for treated nests, because for control nests, only one cell had more than five observations. Our alpha value for all tests was 0.1 , because our sample size was small and we considered that in our circumstances a reduction in Type II error was better than a Type I error.

\section{Results}

We recorded 20 nests in TE and 27 nests in AE. In each treatment, we assigned: (1) control: $\mathrm{TE}=$ six nests, $\mathrm{AE}=11$ nests; (2) visual attraction: $\mathrm{TE}=$ three nests, $\mathrm{AE}=$ three nests; (3) olfactory attraction: $\mathrm{TE}=$ four nests, $\mathrm{AE}=$ three nests; and (4) olfactory attraction from human disturbance: $\mathrm{TE}=$ seven nests, $\mathrm{AE}$ $=10$ nests.

The overall nest predation rate of control nests of Caiman latirostris at this site in 2010 was $21 \%$ [(33\% TE $+9 \% \mathrm{AE}) / 2]$. The predation rate of control nests was not significantly different between the terrestrial nests $(33 \%, 2$ of 6 nests) and aquatic nests $\left(9 \%, 1\right.$ of 11 nests; $\chi^{2}=$ $1.47, P=0.2102)$. The predation rate was greater in treated terrestrial nests $(57 \%, 8$ of 14 nests) than in treated aquatic nests $(25 \%, 4$ of 16 nest; $\left.\chi^{2}=3.21, P=0.0730\right)$. Treated nests had a greater predation rate $(40 \%, 12$ of 30 nests) than control nests $(21 \%, 3$ of 17 nests $),\left(\chi^{2}=10.379\right.$,

Table 1. Number of Caiman latirostris nests depredated and not depredated recorded for each treatment.

\begin{tabular}{|c|c|c|c|c|}
\hline \multirow{2}{*}{ Treatment } & \multicolumn{2}{|c|}{ Aquatic environment } & \multicolumn{2}{|c|}{ Terrestrial environment } \\
\hline & Depredated & Not depredated & Depredated & Not depredated \\
\hline Control & 1 & 10 & 2 & 4 \\
\hline Visual attraction & 1 & 2 & 1 & 2 \\
\hline Olfactory attraction & 2 & 1 & 2 & 2 \\
\hline $\begin{array}{l}\text { Olfactory attraction from } \\
\text { human disturbance }\end{array}$ & 1 & 9 & 5 & 2 \\
\hline
\end{tabular}


$P=0.0013$; Table 1). Approximately $50 \%$ (6 of 13) of nests with olfactory or visual attraction were depredated (terrestrial and aquatic nests pooled). Only 1 of 10 nests exposed to the human disturbance was depredated in the aquatic environments, and more than $70 \%$ (5 of 7) terrestrial nests were depredated (Table 1).

Although the sample size was small, our findings indicate no differences between depredation rates for aquatic and terrestrial nests. It should be mentioned that we did not find flooded nests in this study. Of the 47 nests studied, we found evidence for female visit (or absence of visit) in 43 nests. We found evidence of female attendance in $70 \%$ of nests (30 of 43 nests). We found that neither our presence nor the disturbance of the nest during treatments affected female attendance when treated nests were compared to control nests $\left(\chi^{2}=0.424, P=\right.$ $0.515)$. Females attended 19 of 28 treated nests $(68 \%)$ and 11 of 15 control nests $(73 \%)$. When we considered only treated nests $(N=28)$ we found that the predation rate was lower in nests attended by females six of 19 nests (32\%) than in non-attended nests (five of nine nests, 56\%; $\left.\chi^{2}=4.402, P=0.0359\right)$.

\section{Discussion}

Under natural conditions, less than $60 \%$ of caiman eggs (Caiman latirostris and C. yacare) hatch in a nesting season under normal weather conditions (Crawshaw and Schaller 1980, Cintra 1988, Larriera and Imhof 2006). The high embryonic mortality in crocodilians may be a result of extreme temperatures, fire, and even fights among females (Joanen and McNease 1981, Ferguson 1985, Webb et al. 1994). However, the main causes of nest loss are flooding and predation (Campos 1993, 2003, Larriera and Piña 2000, Cooper and Slaughter 2008, Vergne et al. 2009). High embryo mortality is part of the rationale for crocodilian management and conservation programs that rely on sustainable harvest of eggs for ranching (Elsey and Trosclair III 2008, Larriera et al. 2008).
Nest predation rates of the American Alligator [Alligator mississippiensis (Daudin, 1802)] were $16.5 \%$ in Louisiana (Joanen 1969), $11 \%$ in South Carolina (Wilkinson 1983), and $51 \%$ to $63 \%$ in Florida (Deitz and Hines 1980, Woodward et al. 1992). In the Pantanal of Brazil nest predation of $C$. yacare has been estimated to be between $27 \%$ and $35 \%$ (Cintra 1988, Campos 1993); and $26 \%$ for the Spectacled Caiman [Caiman crocodilus crocodilus (Linnaeus, 1758)] in Central Amazonia (Barão-Nóbrega et al. 2014). These values are similar to those found in the present study for $C$. latirostris, with a predation rate $21 \%$ for control nests.

There are many factors that influence variation in nest predation rate of $C$. latirostris among nesting seasons. In this study (2010), rainfall was normal (no presence of extreme ENSO events, El Niño Southern Oscillation) and we found about $20 \%$ of the nests of $C$. latirostris depredated in the wild. Campos (1993) reported that predation rates on crocodilian nests can vary between nesting habitats. Terrestrial environments facilitate the approach of nests by predators, and allow repeated visits to nests to eat all eggs (Platt et al. 2008). Mound-nesting crocodilian species frequently build nests on elevated sites in wetlands (or floating vegetation, as in C. latirostris) (Montini et al. 2006), possibly because the surrounding aquatic environment would make access by predators more difficult, thereby reducing nest losses (Webb et al. 1983, Platt et al. 2008). Although, we observed a predation rate in terrestrial nests of $33 \%$ and a predation rate in aquatic nests $9 \%$, we did not find significant difference, probably because of a low sample size of control nests.

Some authors have suggested that a negative relationship exists between predation and water level. Their hypotheses are (1) that higher water not only hinders access to nests by predators but also (2) the proximity of nests to water increases female attendance (Cintra 1988, Hunt and Ogden 1991, Larriera and Piña 2000). Our findings on female attendance of treated nests indicate that female presence decreased predation rate, thus 
supporting the latter hypothesis. Nest attendance and defensive behavior by females was common in Crocodylus acutus (Cuvier, 1807) and Caiman c. crocodilus in some locations and were associated with decreased nest predation rates (Thorbjarnarson 1989, Charruau 2012, BarãoNóbrega et al. 2014). However, many studies mentioned that presence of female crocodilians near nests did not improve nest survival (Magnusson 1980, Joanen and McNease 1989, Vergne and Mathevon 2008, Charruau and Hénaut 2012). Most maternal female Alligator mississippiensis (in Texas) return to their nest to add vegetation (more frequently immediately after building nests and laying eggs; and to open the nest at the time of hatching) (Savage and Merchant 2012). Deitz and Hines (1980) found that some female A. mississippiensis defended their nests, but not with high frequency. In contrast, we observed a lower predation rate in treated and manipulated nests attended by female Caiman latirostris than in unattended nests. Apparently, female nest defense behavior is not consistent across crocodilian species (Brazaitis and Watanabe 2011, Charruau and Hénaut 2012).

Some authors speculated that human disturbance caused lower nest attendance because crocodilians rarely stay on their nest when humans are present (Deitz and Hines 1980, Hunt and Ogden 1991). However, Barão-Nóbrega et al. (2014) showed that nest manipulation and the presence of researchers did not affect female nest attendance in Caiman c. crocodilus. In this study, our presence near the nests did not seem to influence the attendance behavior of female $C$. latirostris, because the ratio of nests attended was similar in both treatment and control nests. About $70 \%$ of the nests of $C$. latirostris were attended by females, a value higher than the $10 \%$ reported for A. mississippiensis in Lousiana (Joanen and McNease 1989), but similar to the $75 \%$ (in 4 nests) reported for C. acutus (Charruau and Hénaut 2012). Some studies reported that even after predation, female A. mississippiensis and $C$. latirostris repair and continue to visit their nests (Hunt and Odgen 1991, Larriera and
Piña 2000, respectively). In conclusion, human interference or activities in the nests of $C$. latirostris do not appear to reduce female attendance.

Predators typically detect prey (in our case, nests) using vision and olfaction (Simpson 1997, Gazit and Terkel 2003), and we speculate that they could learn to recognize caiman nests from certain cues, as is the case for mongooses, which learn to recognize sea turtle nesting sites and the time of nesting (Nellis and Small 1983). Predators of turtle eggs detect nests by smell, whereas others locate nests visually, identifying disturbances on the ground where nests were built (Geluso 2005, Leighton et al. 2009). Jones and Sievert (2011) mentioned that turtle hatchlings are easily identified by predators when they are marked with fluorescent powders, indicating that predators could detect marked turtles by vision. We observed that treated nests (with visual or olfactory attraction) had higher predation rates than control nests. We also found that both aquatic and terrestrial treated nests were depredated (3 of 7 terrestrial and 3 of 6 aquatic), but we found that terrestrial nests disturbed by humans had a greater predation rate $(71 \%)$ than the aquatic nests $(10 \%)$. This could be because terrestrial predators may associate humans with a food source. This is supported by findings for Crocodylus porosus Schneider, 1801, C. latirostris and C. yacare, in which an increased predation on nests followed disturbance by researchers (Deitz and Hines 1980, Magnusson 1982, Campos 1993, 2003, Larriera and Piña 2000).

In summary, we found that predation rates are greater in treated nests, that predation of treated aquatic nests is lower than in terrestrial nests, and that higher predation rates of nests are associated with olfactory and visual cues in both types of nests. Human presence attracted more predators in terrestrial than in aquatic nests. Therefore, to minimize egg losses and maximize egg production for management programs based on egg harvests, we recommend that nests should not be marked using visual signs in either 
terrestrial or aquatic nesting environments, because it may increase the chances of predation, and that nests in terrestrial environments should be collected when found because the human presence increases predation rates.

\section{Acknowledgments}

We thank other members of Proyecto Yacaré. This study was supported by Proyecto Yacaré, Yacarés Santafesinos (Gob. Prov. de Santa Fe/ MUPCN), PFIP 2008; and PICT 2014 N2138 (to C. Piña), PICT 2014 N2212 (to M. Simoncini), CAID 2013 PI 50120220100222LI (to A. Larriera). We appreciate comments and suggestions of the manuscript by A. Woodward and two anonymous reviewers. This is publication 93 from Proyecto Yacaré.

\section{References}

Barão-Nóbrega, J. A. L., B. Marioni, F. Villamarín, A. M. V. M. Soares, W. E. Magnusson, and R. Da Silveira. 2014. Researcher disturbance has minimal impact on natural predation of caiman nests in Central Amazonia. Journal of Herpetology 48: 338-342.

Brazaitis, P. and M. E. Watanabe. 2011. Crocodilian behaviour: a window to dinosaur behaviour? Historical Biology 23: 73-90.

Campos, Z. 1993. Effect of habitat on survival of eggs and sex ratio of hatchlings of Caiman crocodilus yacare in the Pantanal, Brazil. Journal of Herpetology 27: 127132.

Campos, Z. 2003. Efeito do habitat na fecundidade das fêmeas, sobrevivência e razão sexual dos jovens de jacarés-do-pantanal. Boletim de Pesquisa e Desenvolvimento/Embrapa Pantanal, Corumbá 42: 1-18.

Campos, Z. and G. Mourão. 2010. Impacts of human interference on predation of the yacare caiman, Caiman crocodilus yacare nests in the Brazilian Pantanal. Pp. 49 in IUCN Species Survival Commission (eds.), Crocodiles: Proceedings of the 20th Working Meeting of the Crocodile Specialist Group. Gland. IUNC-The World Conservation Union.

Charruau, P. 2012. Microclimate of American crocodile nests in Banco Chinchorro biosphere reserve, Mexico: effect on incubation length, embryos survival and hatchlings sex. Journal of Thermal Biology 37: 6-14.

Charruau, P. and Y. Hénaut. 2012. Nest attendance and hatchling care in wild American crocodiles (Crocodylus acutus) in Quintana Roo, Mexico. Animal Biology 62: 29-51.

Cintra, R. 1988. Nesting ecology of the Paraguayan Caiman (Caiman yacare) in the Brazilian Pantanal. Journal of Herpetology 22: 219-222.

Cooper, A. and M. J. Slaughter. 2008. Nesting success of American alligators in a southeast Texas coastal marsh. Proceedings of the Annual Conference of Southeastern Association Fish and Wildlife Agencies 62: 204.

Crawshaw, P. G. and G. Schaller. 1980. Nesting of Paraguayan caiman, Caiman yacare, in Brazil. Papéis Avulsos de Zoologia 33: 283-292.

Deitz, D. C. and T. C. Hines. 1980. Alligator nesting in north-central Florida. Copeia 1980: 249-258.

Elsey, R. M. and P. L. Trosclair III. 2008. Effect of timing of egg collection on growth in hatchling and juvenile American alligators. Herpetological Bulletin 105: 1318.

Ferguson, M. W. J. 1985. The reproductive biology and embryology of the crocodilians. Pp. 329-491 in C. Gans, F. S. Billet, and P. F. A. Maderson (eds), Biology of the Reptilia. Development A. New York. John Wiley and Sons.

Gazit, I. and J. Terkel. 2003. Domination of olfaction over vision in explosives detection by dogs. Applied Animal Behaviour Science 82: 65-73.

Geluso, K. 2005. Benefits of small-sized caches for scatterhoarding rodents: influence of cache size, depth, and soil moisture. Journal of Mammalogy 86: 1186-1192.

Hunt, R. H. and J. J. Ogden. 1991. Selected aspects of the nesting ecology of American alligators in the Okefenokee swamp. Journal of Herpetology 25: 448-453.

Iungman, J., C. I. Piña, and P. Siroski. 2008. Embryological development of Caiman latirostris (Crocodylia: Alligatoridae). Genesis 46: 401-417.

Jennings, M. L., H. F. Percival, and C. L. Abercrombie. 1987. Habitat variables affecting nesting success of the American alligator in Florida. Proceeding Annual Conference Southeastern Association Fish and Wildlife Agencies 41: 334-342.

Joanen, T. 1969. Nesting ecology of alligators in Louisiana. Proceeding of the Annual Conference of Southeastern Association of Fish and Wildlife Commissioners 23: $141-151$. 
Joanen, T. and L. McNease. 1981. Nesting chronology of the American alligator and factors affecting nesting in Louisiana. Proceeding of the Annual Alligator Production Conference 1: 107-116.

Joanen, T. and L. L. McNease. 1989. Ecology and physiology of nesting and early development of the American alligator. American Zoologist 29: 987-998.

Jones, M. T. and P. R. Sievert. 2011. Elevated mortality of hatchling Blanding's Turtles (Emydoidea blandingii) in residential landscapes. Herpetological Conservation and Biology 7: 89-94.

Lance, V. A., R. M. Elsey, P. L. Trosclair III, and L. A. Nunez. 2011. Long-distance movement by American alligators in Southwest Louisiana. Southeastern Naturalist 10: 389-398.

Larriera, A. 2011. Ranching the broad-snouted caiman (Caiman latirostris) in Argentina: an economic incentive for wetland conservation by local inhabitants. Pp. 86-92 in M. Abensperg-Traun, D. Roe, and C. O'Criodain (eds.), Proceedings of an International Symposium on The relevance of Community-Based Natural Resources Management (CBNRM) to the Conservation and Sustainable Use of CITES-Listed Species in Exporting Countries". Vienna. European Commission Directorate General Environment.

Larriera, A. and C. I. Piña. 2000. Caiman latirostris (BroadSnouted Caiman) nest predation: does low rainfall facilitate predator access? Herpetological Natural History 7: 73-77.

Larriera, A. and A. Imhof. 2006. Proyecto Yacaré. Cosecha de huevos para cría en granjas del género Caiman en la Argentina. Pp. 51-64 in M. L. Bolkovic and D. Ramadori (eds.), Manejo de Fauna Silvestre en la Argentina. Programas de uso sustentable. Buenos Aires. Dirección de Fauna Silvestre, Secretaría de Ambiente y Desarrollo Sustentable.

Larriera, A., A. Imhof, and P. Siroski. 2008. Estado actual de los programas de conservación y manejo del género Caiman en Argentina. Pp. 141-180 in J. Castroviejo, J. Ayarzaguena, and A. Velasco (eds.), Contribución al Conocimiento del Género Caiman de Sudamérica. Madrid. Publicaciones de la Asociación Amigos de Doña Ana.

Leighton, P. A., J. A. Horrocks, and D. L. Kramer. 2009. How depth alters detection and capture of buried prey: exploitation of sea turtle eggs by mongooses. Behavioural Ecology 20: 1299-1306.

Magnusson, W. E. 1980. Habitat required for nesting by Crocodylus porosus (Reptilia: Crocodilidae) in northern Australia. Australian Journal Wildlife Research 7: 149-156.
Magnusson, W. E. 1982. Mortality of eggs of the crocodile Crocodylus porosus in Northern Australia. Journal of Herpetology 16: 121-130.

Montini, J. P., C. I. Piña, A. Larriera, P. Siroski, and L. M. Verdade. 2006. The relationship between nesting habitat and hatching success in Caiman latirostris (Crocodylia, Alligatoridae). Phyllomedusa 5: 91-96.

Nellis, D. W. and V. Small. 1983. Mongoose predation on sea turtle eggs and nests. Biotropica 15:159-160.

Parachú Marcó, M. V., C. I. Piña, and A. Larriera. 2012. Presence of red fire ants (Solenopsis invicta Buren) in broad-snouted caiman (Caiman latirostris) nests. Journal of Herpetology 46: 228-232.

Parachú Marcó, M. V., A. Larriera, and C. I. Piña. 2013. Impacts of red imported fire ants Solenopsis invicta on survivorship of hatchlings of the broad-snouted caiman Caiman latirostris. Zoological Studies 52: 52.

Platt, S. G., T. R. Rainwater, J. B. Thorbjarnarson, and S. T. McMurry. 2008. Reproductive dynamics of a tropical freshwater crocodilian: Morelet's crocodile in northern Belize. Journal of Zoology 275: 177-189.

Savage, D. and M. Merchant. 2012. Nest Defence Strategies of the American Alligator (Alligator mississippiensis). Gland and Cambridge. SRAS Report, Crocodile Specialist Group, SSC/IUCN.

Simoncini, M. S., F. B. Cruz, and C. I. Piña. 2013. Effects of environmental temperature on the onset and the duration of oviposition period of Caiman latirostris. Herpetological Conservation Biology 8: 409-418.

Simpson, B. S. 1997. Canine communication. Veterinary Clinic of North America: Small Animal Practice 27: 445-464.

Strickland, J., P. Colbert, and F. J. Janzen. 2010. Experimental analysis of effects of markers and habitat structure on predation of turtle nests. Journal of Herpetology 44: 467-470.

Thorbjarnarson, J. B. 1989. Ecology of the American crocodile, Crocodylus acutus. Pp. 228-258 in P. M. Hall (ed.), Crocodiles: Their Ecology, Management, and Conservation. Gland. IUCN Publications New Series.

Vergne, A. L. and N. Mathevon. 2008. Crocodile egg sounds signal hatching time. Current Biology 18: 513-514.

Vergne, A. L., M. B. Pritz, and N. Mathevon. 2009. Acoustic communication in crocodilians: from behaviour to brain. Biological Reviews of the Cambridge Philosophical Society 84: 391-411.

Webb, G. J. W., R. Buckworth, and S. C. Manolis. 1983. Crocodylus johnstoni in the McKinaly River, N.T, VI. 
Nesting Biology. Australian Wildlife Research 10: 607637.

Webb, G. J. W., S. C. Manolis, and B. Ottley. 1994. Crocodile management and research in the northern territory 1992-1994. Pp. 167-180 in IUCN Species Survival Commission (eds.), Crocodiles. Proceeding of the $12^{\text {th }}$ Working Meeting of the Crocodile Specialist Group. Pattaya. IUNC-The World Conservation Union.

Wilkinson, P. M. 1983. Nesting Ecology of the American Alligator in Coastal South Carolina. Study Completion
Report August 1978-September 1983. Charleston. South Carolina Wildlife and Marine Resources Department, Division of Wildlife and Freshwater Fisheries. 114 pp.

Woodward, A. R., M. L. Jennings and H. F. Percival. 1989. Egg collecting and hatch rates of American alligator eggs in Florida. Wildlife Society Bulletin 17: 124-130.

Woodward, A. R., C. T. Moore, and M. F. Delany. 1992. Experimental Alligator Harvest. Final Report Study Number 7567. Gainesville. Florida Game and Fresh Water Fish Commission. 118 pp.

Editor: Peter A. Meylan 